\title{
ANALYSIS OF MAJOR GREENHOUSE GASES (GHGS) AROUND SOME INDUSTRIAL AREAS IN RIVERS STATE, NIGERIA
}

\author{
Nyeche V. W' ${ }^{1}$ Obafemi A. A. ${ }^{1,2}$ and Ndukwu, B. C. ${ }^{1,3}$ \\ ${ }^{1}$ Institute of Natural Resources Environment and Sustainable Development, Faculty of Science, University of Port \\ Harcourt, Port Harcourt, Rivers State, Nigeria \\ ${ }^{2}$ Department of Geography and Environmental Management, Faculty of Social Sciences, University of Port \\ Harcourt, Port Harcourt, Rivers State, Nigeria. \\ ${ }^{3}$ Department of Plant Science and Biotechnology, Faculty of Science, University of Port Harcourt, Port Harcourt, \\ Rivers State, Nigeria
}

http://doi.org/10.35410/IJAEB.2019.4470

\begin{abstract}
The study analyzed major GHGs around some selected industrial areas in Rivers State, Nigeria. In situ air measurements were randomly carried out around five industrial areas in Bonny, Eleme, Omoku, Rumuolumeni and Trans-Amadi. Descriptive statistics were employed for data presentation. Inferential statistics in the use of ANOVA analysis and Pearson Correlation statistics were employed for data analysis. Finding showed that the concentration of $\mathrm{CO} 2$ $(\mathrm{mg} / \mathrm{m} 3)$ were significantly high around sampled industrial areas; recording mean and \% values of $1251.9 \mathrm{mg} / \mathrm{m} 3$ (0.07\%) for Bonny; $1159.7 \mathrm{mg} / \mathrm{m} 3$ (0.06\%) for Eleme; $1208.3 \mathrm{mg} / \mathrm{m} 3(0.07 \%)$ for Omoku; $1111.5 \mathrm{mg} / \mathrm{m} 3(0.06 \%)$ for Rumuolumeni; and $1074.2 \mathrm{mg} / \mathrm{m} 3(0.05 \%)$ for TransAmadi. The results showed that $\mathrm{CO} 2$ concentration were higher than the WHO air quality standards. The concentration of $\mathrm{CH} 4(\mathrm{mg} / \mathrm{m} 3)$ was $461.4 \mathrm{mg} / \mathrm{m} 3(0.07 \%)$ in Bonny; 455.8 $\mathrm{mg} / \mathrm{m} 3(0.07 \%)$ in Eleme; $373.6 \mathrm{mg} / \mathrm{m} 3(0.06 \%)$ in Omoku; $325.4 \mathrm{mg} / \mathrm{m} 3(0.05 \%)$ in Rumuolumeni; $339.7 \mathrm{mg} / \mathrm{m} 3(0.05 \%)$ in Trans-Amadi. However, the concentrations of $\mathrm{CH} 4$ in sampled industrial areas were lower than the permissible limit of NIOSH. The mean concentrations of $\mathrm{CO} 2$ and $\mathrm{CH} 4$ in Rumuolumeni and Trans-Amadi recorded lower values when compared with the other industrial areas in Rivers State. Findings revealed no significant correlation between temperature (0C) and RH (\%) with GHGs; but findings revealed a negative but strong and significant correlation between wind speed $(\mathrm{m} / \mathrm{s})$ and the concentration of $\mathrm{CO} 2$ $(\mathrm{mg} / \mathrm{m} 3) \quad(\mathrm{r}=-0.810 ; \mathrm{p}<0.05)$; however, correlation with $\mathrm{CH} 4(\mathrm{mg} / \mathrm{m} 3)$ was weak and not significant $(\mathrm{r}=-0.364 ; \mathrm{p}<0.05)$ in the study area. The findings of the study revealed high concentrations of GHGs which have several health and environmental implications. The study therefore recommends that Government should endeavour to strengthen existing laws on air pollution.
\end{abstract}

Keywords: GHGs, $\mathrm{CO}$, $\mathrm{CH} 4$, WHO, Climate Change, Industrial areas.

\section{INTRODUCTION}

The change in climate variables is usually attributed to human activity as opposed to changes caused by earth's natural processes (UNFCCC, 2013). Climate change has overtime become 
identical with global warming which refers to surface temperature increase; however, climate change include global warming and everything else that increases the level of GHGs effect (NASA, 2011). Similarly, there exists strong credible evidence in relation to several lines of research (NAP, 2010; IPCC, 2014; UNEP, 2018; WMO, 2019) stating that climate is changing and it is largely caused by anthropogenic factors currently increasing carbon dioxide $\left(\mathrm{CO}_{2}\right)$ and methane $\left(\mathrm{CH}_{4}\right)$ levels in the atmosphere. The contribution of GHGs in the atmosphere is related to what is called the greenhouse effect. This greenhouse effect is essential for man as it aids in the regulation of the earth surface temperatures without which would have been a lot colder and maybe less fit for plants, animals and human habitation. According to a postulation highlighted by Chigbo (2011) and Braatz (2013) without the greenhouse effect the earth would have been about $33^{\circ} \mathrm{C}$ colder than the present condition. Palmer and McNeall (2014) reiterate that these emissions from fossil fuel combustion, followed by aerosols (particles in air) cement manufacturing, land use, ozone depletion, animal husbandry (ruminant animals, decaying vegetation), coal and natural gas plant, deforestation and other sources of $\mathrm{CO}_{2}$ and $\mathrm{CH}_{4}$ act distinctively or in conjunction with other variables to affect the climate. Shah (2011) highlighted how the effect of excess $\mathrm{CO}_{2}, \mathrm{CH}_{4}, \mathrm{NO}_{\mathrm{x}}$ and other chlorofluorocarbons (CFCs) in air constitute to global warming because these gases build up and increase the greenhouse effect leading to global warming with its consequential effect on local temperature, humidity, wind speed, precipitation, soil moisture, sea level anomalies and changes in climate conditions overtime. In 2007, IPCC submitted that there has been a global increase of the atmospheric mixing ratio of $\mathrm{CO}_{2}$ by $100 \mathrm{ppm}(36 \%$ ) over the last 250 years, and this resulted from a range of $275 \mathrm{ppm}$ to 285 $\mathrm{ppm}$ in the pre-industrial era to $379 \mathrm{ppm}$ in 2005 (industrial era). Houghton (2003) pointed out that the period of industrial evolution ushered in increase in $\mathrm{CO}_{2}$ concentration as a result of combustion of fossil fuels, gas flaring and cement production. Methane, however, since the 90s has recorded a relatively equal concentration before 2006; but recorded a steady increase in concentration between 2007 and 2017 with a total rise of $75 \mathrm{ppb}$ and a global mean of $1850 \mathrm{ppb}$ in 2017 (Nisbet et al., 2019). Etheridge et al., (1998) asserts that the concentration of methane during the pre-industrial era was $720 \mathrm{ppb}$ and has increased considerably by $6 \%$ of the total growth from the beginning of industrialization to date. Canadell and Jackson (2019) discussed that from pre-industrial times till date methane concentration in the atmosphere has increased by 150 times.

Industrialization is desired becomes it holds numerous opportunities. Thus, humans have overtime embarked on heavy industrialization in the quest to improve their lot economically and to promote better living conditions; but these activities affect the environment and contribute to air pollution if not carried out sustainably (Chigbo, 2011; WHO, 2015). Nordell (2011) highlighted that about $98 \%$ of carbon dioxide emissions $\left(\mathrm{CO}_{2}\right), 24 \%$ of methane gas $\left(\mathrm{CH}_{4}\right)$ emissions and $18 \%$ of nitrous oxide (NOx) emissions are due to fossil fuels burned to run cars and trucks, heat homes and businesses and power factories. But quite a significant share of emissions is due to increased agriculture, deforestation, landfills, industrial productions and mining activities. According to the USAID (2019) the most recent estimates revealed that Nigeria is responsible for 490 metric tonnes of GHG emissions $\left(\mathrm{CO}_{2}\right.$ equivalent) annually, just over 1 percent of global production; 39 percent of this arises from land-use change and forestry; 33 percent from energy production (oil and gas extraction, and the power sector); 14 percent from waste (incineration of municipal waste); 13 percent from agriculture; and 2 percent from 
industry. According to WRI CAIT (2017) cited in USAID (2019) Nigeria's GHG emissions increased 25\% between 1990 and 2014, averaging 1\% annually, while GDP grew 245\%, averaging 5.5\% annually. Although GDP grew faster than GHG emissions, in 2014, Nigeria's emissions relative to GDP were 1.6 times the world average, indicating potential for improvement.

The purpose of the study was to analyze major GHGs around some industrial areas in Rivers State, Nigeria using in situ measurements of air around selected industries at experimental sites from the pollution source. Thus, the study presented information on the status of key weather parameters and GHGs and the relationship between them. The results of these measurements will aid in the understanding of the status of air quality as regards $\mathrm{CO}_{2}$ and $\mathrm{CH}_{4}$ around industrial areas in Rivers State and promote reasons for sustainable use of resources, and the need to embrace alternative energy source to reduce gas emissions.

\section{MATERIALS AND METHODS Description of the Study Area}

The study was carried out in some industrial areas comprising Bonny, Eleme, Omoku, Rumuolumeni and Trans-Amadi in Rivers State, Nigeria. The study area is found in latitudes between $4^{\circ} 00^{\prime} 00^{\prime \prime} \mathrm{N}$ and $5^{\circ} 40^{\prime} 00^{\prime \prime} \mathrm{N}$ and longitudes between $6^{\circ} 20^{\prime} 00^{\prime \prime} \mathrm{E}$ and $7^{\circ} 40^{\prime} 0^{\prime \prime} \mathrm{E}$ (Figure 1). The study area enjoys tropical hot monsoon climate due to its latitudinal position. The tropical monsoon climate is characterized by heavy rainfall from April to October ranging from 2000 to $2500 \mathrm{~mm}$ with high temperature all the year round and a relatively constant high humidity (Wokocha and Omenihu, 2015). The geology of the area comprises basically of alluvial sedimentary basin and basement complex (Eludoyin et al., 2011; Igbokwe et al., 2016). The vegetation found in this area includes raffia palms, thick mangrove forest and rain forest. The soil is usually sandy or sandy loam underlain by a layer of impervious pan and is always leached due to the heavy rainfall experienced in this area (Eludoyin et al., 2011). The population of the study area increases on a daily basis, and population rose from 1,200,000 to over 5,000,000 residents in 2006 (National Population Census, 2006). The population of Rivers State has been projected to 7,043,800 people in 2015 by the National Bureau of Statistics (NBS) (2016). The transport network is accessible through local, regional, national and international means (McKenna, 2018). There are adequate transportation means via road network and inland water ways, bringing people in and out of the area. The major socio-economic occupation of the people of Rivers State was mainly farming and fishing (McKenna, 2018). However, at present, urban growth has ushered in several socio-economic activities into the area, such as trading (import/export), transportation (land, water and air), and exploration and oil production, as well as, craftsmanship and tourism (McKenna, 2018). 


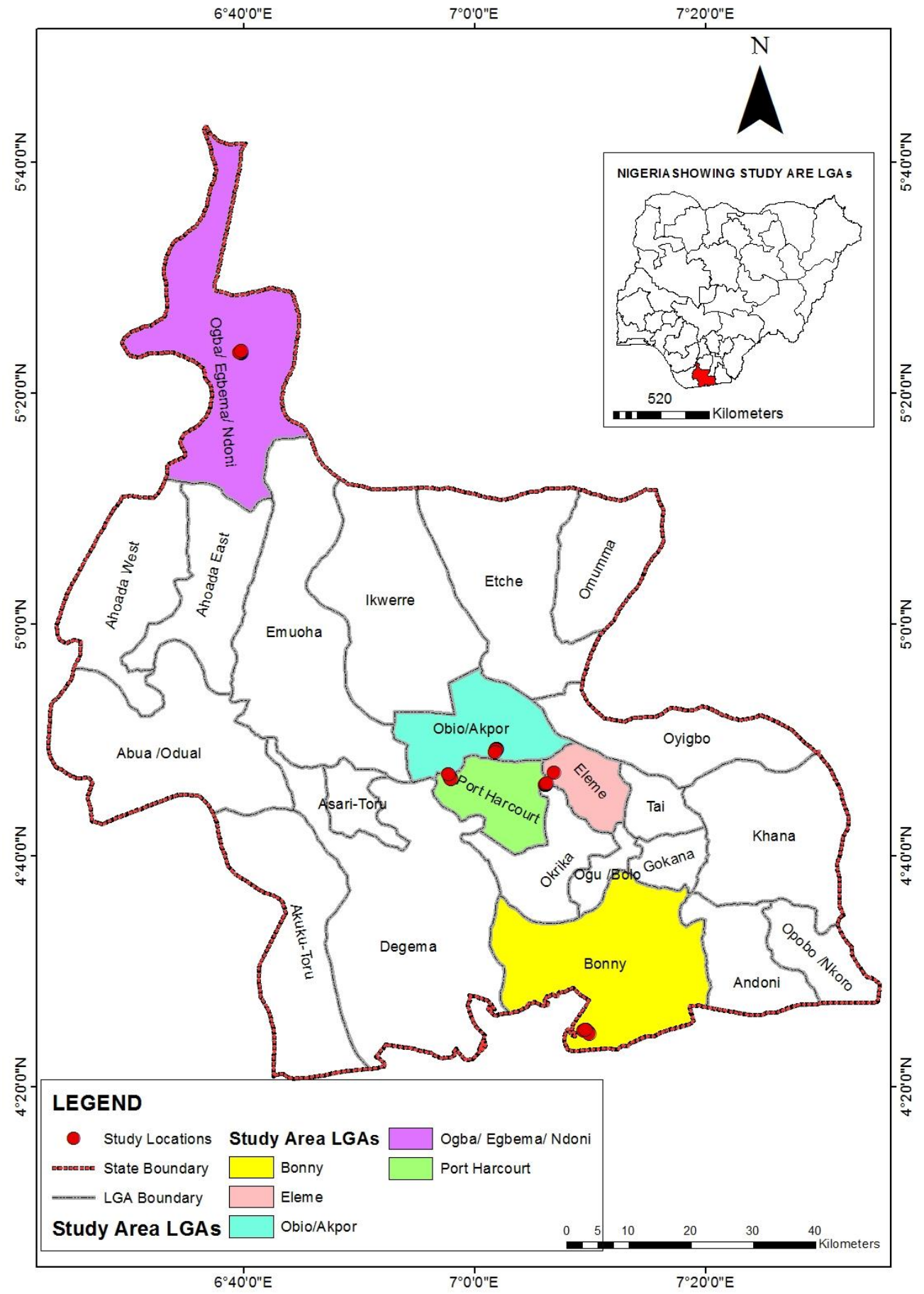

Figure 1: Administrative Map of Rivers State showing Study area LGAs

Measurement of Meteorological Parameters and GHGs and Data Analysis 
The field measurements of key meteorological parameters of temperature, relative humidity $(\mathrm{RH})$, and wind speed and wind direction were measured with a hand held Met-One Weather station meter. The measurement for GHGs of $\mathrm{CO}_{2}$ and $\mathrm{CH}_{4}$ was carried out with Aero Qual equipments which is a digital environmental monitor with non dispersive infra red (NDIR) sensor type that features range of measurement for gaseous concentrations at five thousand (5000) parts per million ( $\mathrm{ppm}$ ) and the detection limit is usually at twenty (20) ppm. Random sampling techniques were employed for in situ measurement of air for each parameter at a height of $1.5 \mathrm{~m}$ above the ground level in the direction of the prevailing wind while reading were recorded at stability. The in situ air measurements were collected at Bonny, Eleme, Omoku, Rumuolumeni and Trans-Amadi industrial areas. The study sampled four (4) stations in each industrial area and the coordinates of sampling stations were also taken with a hand held global positioning systems (GPS) Garmin model. The information on Table 1 presents the geographic coordinates of sampling stations for in situ measurements of air for meteorological parameters and status of GHGs in each industrial area. All samples of air measurements were collected in each industrial area between 9am and $2 \mathrm{pm}$ (5 hour monitoring period) per day with the help of four (4) field assistants who are knowledgeable on the use and recording of air measurements at the different sampling stations in the study area. The field measurements were carried out in May, 2019. Air quality standards of World Health Organization (WHO) (2009) for $\mathrm{CO}_{2}$ and National Institute for Occupational Safety and Health (NIOSH) (2019) permissible limits for $\mathrm{CH}_{4}$ were obtained in some literatures for comparison purposes. Both descriptive and inferential statistics was employed for data presentation and analysis. The variations in GHGs among sampled industrial areas were computed using ANOVA statistics while the relationship between meteorological parameters and GHGs was computed using Pearson Correlation Statistics. Each of the meteorological parameters was regarded as the independent variable $(\mathrm{X})$ while each of the GHGs was the dependent variable (Y). All statistical analysis was performed using SPSS 24 and Excel worksheet 2010.

Table 1: Locations of In situ Air Quality Measurement of Weather Parameters \& Status of GHGs

\begin{tabular}{|c|c|c|}
\hline & Bonny & \\
\hline $\mathrm{S} / \mathrm{N}$ & Stations & Location \\
\hline 1 & S1 & N $04024^{\prime} 58.90 "$ E 0070 2' $12.38 "$ \\
\hline 2 & S2 & N 040 24' 37.29" E 0070 2' 19.20" \\
\hline 3 & S3 & N 040 24' 51.91" E $007009^{\prime} 25.70 "$ \\
\hline \multirow[t]{2}{*}{4} & S4 & N 040 24' 55.84" E $007000^{\prime} 36.12 "$ \\
\hline & Eleme & \\
\hline $\mathrm{S} / \mathrm{N}$ & Stations & Location \\
\hline 1 & S1 & N $04^{0} 46^{\prime} 32.67^{\prime \prime}$ E $007^{0} 6^{\prime} 31.33^{\prime \prime}$ \\
\hline 2 & S2 & N 04ㅇ 46' 58.86" E $007^{0} 56^{\prime} 6.59^{\prime \prime}$ \\
\hline 3 & S3 & N 040 48' 8.66" E 007º 6' 14.19" \\
\hline \multirow[t]{2}{*}{4} & S4 & N $04^{0} 48^{\prime} 48.19^{\prime \prime}$ E $007^{0} 5^{\prime} 49.56^{\prime \prime}$ \\
\hline & Omoku & \\
\hline $\mathrm{S} / \mathrm{N}$ & Stations & Location \\
\hline 1 & S1 & N $05^{0} 14^{\prime} 34.34^{\prime \prime}$ E $006^{0} 37^{\prime} 45.93^{\prime \prime}$ \\
\hline
\end{tabular}




\begin{tabular}{|c|c|c|}
\hline 2 & S2 & N $05^{0} 13^{\prime} 43.36^{\prime \prime}$ Е $006^{0} 38^{\prime} 3.03^{\prime \prime}$ \\
\hline 3 & S3 & 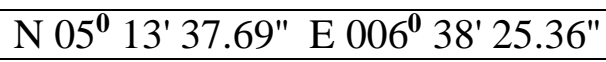 \\
\hline \multirow[t]{2}{*}{4} & S4 & N $05^{\circ} 18^{\prime} 21.81^{\prime \prime}$ Е $006^{0} 39^{\prime} 8.70^{\prime \prime}$ \\
\hline & Rumuolumeni & \\
\hline $\mathrm{S} / \mathrm{N}$ & Stations & Location \\
\hline 1 & S1 & N $04^{0} 46^{\prime} 30.53^{\prime \prime}$ Е $006^{0} 58^{\prime} 15.85^{\prime \prime}$ \\
\hline 2 & S2 & $\mathrm{N} 04^{0} 46^{\prime} 33.92^{\prime \prime}$ E $006^{0} 58^{\prime} 2.74^{\prime \prime}$ \\
\hline 3 & S3 & $\mathrm{N} 04^{0} 46^{\prime} 51.75^{\prime \prime}$ Е $006^{0} 57^{\prime} 49.12^{\prime \prime}$ \\
\hline \multirow[t]{2}{*}{4} & S4 & $\mathrm{N} 04^{0} 47^{\prime} 8.08^{\prime \prime}$ E $006^{0} 57^{\prime} 46.69^{\prime \prime}$ \\
\hline & Trans-Amadi & \\
\hline $\mathrm{S} / \mathrm{N}$ & Stations & Location \\
\hline 1 & S1 & 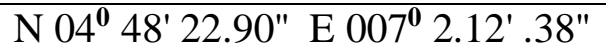 \\
\hline 2 & S2 & N $04^{0} 48^{\prime} 37.29^{\prime \prime}$ E $007^{0} 2^{\prime} 19.20^{\prime \prime}$ \\
\hline 3 & S3 & N $04^{0} 49^{\prime} 38.99^{\prime \prime}$ E $007^{0} 2^{\prime} 9.26^{\prime \prime}$ \\
\hline 4 & S4 & $\mathrm{N} 04^{0} 49^{\prime} 1.11^{\prime \prime}$ E $007^{0} 1^{\prime} 55.35^{\prime \prime}$ \\
\hline
\end{tabular}

Source: Researcher's analysis, 2019

Results of in situ Measurements for Meteorological Parameters and Status of GHGs

The results of in situ measurements of meteorological parameters and status of GHGs were displayed on Table 2. The information displayed revealed their mean values as well as the comparison values of WHO standards and NIOSH permissible limits. The discussions of the results are as follows:

Bonny: The results obtained for RH (\%) ranged between $62.2 \%$ and $71.5 \%$ with a mean of $66.5 \%$, the wind speed ranged between $0.8 \mathrm{~m} / \mathrm{s}$ and $1.2 \mathrm{~m} / \mathrm{s}$ with a mean value of $1.0 \mathrm{~m} / \mathrm{s}$, while temperature ranged between $31.0{ }^{\circ} \mathrm{C}$ and $31.6^{\circ} \mathrm{C}$ with a mean value of $30.0 .{ }^{\circ} \mathrm{C}$. The measured concentration values of $\mathrm{CO}_{2}\left(\mathrm{mg} / \mathrm{m}^{3}\right)$ ranged from $1182.6 \mathrm{mg} / \mathrm{m}^{3}$ to $1292.4 \mathrm{mg} / \mathrm{m}^{3}$ with a mean concentration value of $1251.9 \mathrm{mg} / \mathrm{m}^{3}$; and for $\mathrm{CH}_{4}\left(\mathrm{mg} / \mathrm{m}^{3}\right)$ the concentration values ranged from $459.9 \mathrm{mg} / \mathrm{m}^{3}$ to $462.5 \mathrm{mg} / \mathrm{m}^{3}$ with a mean concentration value of $461.4 \mathrm{mg} / \mathrm{m}^{3}$. For percentage composition of GHGs, taking $10,000 \mathrm{ppm}=18,000.09 \mathrm{mg} / \mathrm{m}^{3}$ for $\mathrm{CO}_{2}$ and 10,000 $\mathrm{ppm}=6560.36 \mathrm{mg} / \mathrm{m}^{3}$ for $\mathrm{CH}_{4}$ (for $\%$ conversion rate); therefore, the $\%$ mean concentration values of $1251.9 \mathrm{mg} / \mathrm{m}^{3}$ for $\mathrm{CO}_{2}$ and $461.4 \mathrm{mg} / \mathrm{m}^{3}$ for $\mathrm{CH}_{4}$ are $0.07 \%$ and $0.07 \%$ respectively. The mean concentration value of $1251.9 \mathrm{mg} / \mathrm{m}^{3}$ for $\mathrm{CO}_{2}$ was higher than the WHO standards of $810 \mathrm{mg} / \mathrm{m}^{3}$ but the mean concentration value of $461.4 \mathrm{mg} / \mathrm{m}^{3}$ for $\mathrm{CH}_{4}$ was found to be lower than the NIOSH permissible limits of $656 \mathrm{mg} / \mathrm{m}^{3}$ for an 8-hour exposure period. It can be concluded that the percentage mean concentration of $0.07 \%$ for $\mathrm{CO}_{2}$ was higher than the WHO standard of $0.04 \%$, but the $\%$ mean concentration of $\mathrm{CH}_{4}$ of $0.07 \%$ was lower than the NIOSH permissible limit of $0.1 \%$ for an 8 -hour period.

Eleme: The results recorded for RH (\%) ranged between $56.4 \%$ and $60.1 \%$ with a mean of $57.7 \%$, the wind speed ranged between $1.0 \mathrm{~m} / \mathrm{s}$ and $2.7 \mathrm{~m} / \mathrm{s}$ with a mean of $2.0 \mathrm{~m} / \mathrm{s}$, while Temperature ranged between $28.0{ }^{\circ} \mathrm{C}$ and $29.1^{\circ} \mathrm{C}$ with a mean of $29.4 .{ }^{\circ} \mathrm{C}$. The measured concentration values of $\mathrm{CO}_{2}\left(\mathrm{mg} / \mathrm{m}^{3}\right)$ ranged from $1098 \mathrm{mg} / \mathrm{m}^{3}$ to $1238.4 \mathrm{mg} / \mathrm{m}^{3}$ with a mean concentration value of $1159.7 \mathrm{mg} / \mathrm{m}^{3}$; and for $\mathrm{CH}_{4}\left(\mathrm{mg} / \mathrm{m}^{3}\right)$ the concentration values ranged from $440.2 \mathrm{mg} / \mathrm{m}^{3}$ to $467.8 \mathrm{mg} / \mathrm{m}^{3}$ with a mean concentration value of $455.8 \mathrm{mg} / \mathrm{m}^{3}$. The $\%$ mean concentration values of $1159.7 \mathrm{mg} / \mathrm{m}^{3}$ for $\mathrm{CO}_{2}$ and $455.8 \mathrm{mg} / \mathrm{m}^{3}$ for $\mathrm{CH}_{4}$ were $0.06 \%$ and 
$0.07 \%$ respectively. The mean concentration value of $1159.7 \mathrm{mg} / \mathrm{m}^{3}$ for $\mathrm{CO}_{2}$ was higher than the WHO standards of $810 \mathrm{mg} / \mathrm{m}^{3}$ but the mean concentration value of $455.8 \mathrm{mg} / \mathrm{m}^{3}$ for $\mathrm{CH}_{4}$ was found to be lower than the NIOSH permissible limits $656 \mathrm{mg} / \mathrm{m}^{3}$ for an 8-hour exposure period. It can be concluded that the percentage mean concentration of $0.06 \%$ for $\mathrm{CO}_{2}$ was higher than the WHO standard of $0.04 \%$, but the \% mean concentration of $\mathrm{CH}_{4}$ of $0.07 \%$ was lower than the NIOSH permissible limit of $0.1 \%$ for an 8 -hour period.

Omoku: The results showed that RH (\%) measurements ranged between $77.7 \%$ and $86.6 \%$ with a mean of $81.2 \%$, the wind Speed ranged between $1.3 \mathrm{~m} / \mathrm{s}$ and $1.6 \mathrm{~m} / \mathrm{s}$ with a mean value of $1.5 \mathrm{~m} / \mathrm{s}$, while Temperature ranged between $28.7^{\circ} \mathrm{C}$ and $28.9^{\circ} \mathrm{C}$ with a mean of $28.8^{\circ} \mathrm{C}$. The measured concentration values of $\mathrm{CO}_{2}\left(\mathrm{mg} / \mathrm{m}^{3}\right)$ ranged from $1150.2 \mathrm{mg} / \mathrm{m}^{3}$ to $1242 \mathrm{mg} / \mathrm{m}^{3}$ with a mean concentration value of $1208.3 \mathrm{mg} / \mathrm{m}^{3}$; and for $\mathrm{CH}_{4}\left(\mathrm{mg} / \mathrm{m}^{3}\right)$ the concentration values ranged from $307.0 \mathrm{mg} / \mathrm{m}^{3}$ to $431.0 \mathrm{mg} / \mathrm{m}^{3}$ with a mean concentration value of $373.6 \mathrm{mg} / \mathrm{m}^{3}$. The $\%$ mean concentration values of $1208.3 \mathrm{mg} / \mathrm{m}^{3}$ for $\mathrm{CO}_{2}$ and $373.6 \mathrm{mg} / \mathrm{m}^{3}$ for $\mathrm{CH}_{4}$ were $0.07 \%$ and $0.06 \%$ respectively. The mean concentration value of $1208.3 \mathrm{mg} / \mathrm{m}^{3}$ for $\mathrm{CO}_{2}$ was higher than the WHO standards of $810 \mathrm{mg} / \mathrm{m}^{3}$ but the mean concentration value of $373.6 \mathrm{mg} / \mathrm{m}^{3}$ for $\mathrm{CH}_{4}$ was found to be lower than the NIOSH permissible limits $656 \mathrm{mg} / \mathrm{m}^{3}$ for an 8 -hour exposure period. Thus, the percentage mean concentration of $0.07 \%$ for $\mathrm{CO}_{2}$ was higher than the WHO standard of $0.04 \%$, but the \% mean concentration of $\mathrm{CH}_{4}$ of $0.06 \%$ was lower than the NIOSH permissible limit of $0.1 \%$ for an 8 -hour period.

Rumuolumeni: It was revealed from the results on Table 2 that $\mathrm{RH}(\%)$ ranged from $62.1 \%$ to $71.4 \%$ with a mean of $64.7 \%$, the wind speed ranged from $1.4 \mathrm{~m} / \mathrm{s}$ to $2.7 \mathrm{~m} / \mathrm{s}$ with a mean of $2.2 \mathrm{~m} / \mathrm{s}$, while Temperature ranged from $30.1^{\circ} \mathrm{C}$ to $31.3^{\circ} \mathrm{C}$ with a mean of $30.9 .{ }^{\circ} \mathrm{C}$. The measured concentration values of $\mathrm{CO}_{2}\left(\mathrm{mg} / \mathrm{m}^{3}\right)$ ranged from $1094.5 \mathrm{mg} / \mathrm{m}^{3}$ to $1130.4 \mathrm{mg} / \mathrm{m}^{3}$ with a mean concentration value of $1111.5 \mathrm{mg} / \mathrm{m}^{3}$; and for $\mathrm{CH}_{4}\left(\mathrm{mg} / \mathrm{m}^{3}\right)$ the concentration values ranged from $314.9 \mathrm{mg} / \mathrm{m}^{3}$ to $331.3 \mathrm{mg} / \mathrm{m}^{3}$ with a mean concentration value of $325.4 \mathrm{mg} / \mathrm{m}^{3}$. The $\%$ mean concentration values of $1111.5 \mathrm{mg} / \mathrm{m}^{3}$ for $\mathrm{CO}_{2}$ and $892.8 \mathrm{mg} / \mathrm{m}^{3}$ for $\mathrm{CH}_{4}$ were $0.06 \%$ and $0.05 \%$ respectively. The mean concentration value of $1111.5 \mathrm{mg} / \mathrm{m}^{3}$ for $\mathrm{CO}_{2}$ was higher than the WHO standards of $810 \mathrm{mg} / \mathrm{m}^{3}$ but the mean concentration value of $325.4 \mathrm{mg} / \mathrm{m}^{3}$ for $\mathrm{CH}_{4}$ was found to be lower than the NIOSH permissible limits of $656 \mathrm{mg} / \mathrm{m}^{3}$ for an 8-hour exposure period. Therefore, it was concluded that the percentage mean concentration of $0.06 \%$ for $\mathrm{CO}_{2}$ was higher than the WHO standard of $0.04 \%$, but the \% mean concentration of $\mathrm{CH}_{4}$ of $0.05 \%$ was lower than the NIOSH permissible limit of $0.1 \%$ for an 8 -hour period in the Rumuolumeni industrial area.

Trans Amadi: The results on Table 2 revealed that RH (\%) measurements ranged from $68.3 \%$ to $77.4 \%$ with a mean of $71.3 \%$, the wind Speed ranged from $1.4 \mathrm{~m} / \mathrm{s}$ to $3.9 \mathrm{~m} / \mathrm{s}$ with a mean of $2.9 \mathrm{~m} / \mathrm{s}$, while Temperature ranged from $28.1^{\circ} \mathrm{C}$ to $30.1^{\circ} \mathrm{C}$ with a mean of $28.9^{\circ} \mathrm{C}$. The measured concentration values of $\mathrm{CO}_{2}\left(\mathrm{mg} / \mathrm{m}^{3}\right)$ ranged from $1051.2 \mathrm{mg} / \mathrm{m}^{3}$ to $1105.2 \mathrm{mg} / \mathrm{m}^{3}$ with a mean concentration value of $1074.2 \mathrm{mg} / \mathrm{m}^{3}$; and for $\mathrm{CH}_{4}\left(\mathrm{mg} / \mathrm{m}^{3}\right)$ the concentration values ranged from $265.7 \mathrm{mg} / \mathrm{m}^{3}$ to $402.2 \mathrm{mg} / \mathrm{m}^{3}$ with a mean concentration value of $339.7 \mathrm{mg} / \mathrm{m}^{3}$. The $\%$ mean concentration values of $1074.2 \mathrm{mg} / \mathrm{m}^{3}$ for $\mathrm{CO}_{2}$ and $339.7 \mathrm{mg} / \mathrm{m}^{3}$ for $\mathrm{CH}_{4}$ were $0.05 \%$ and $0.05 \%$ respectively. The mean concentration value of $1074.2 \mathrm{mg} / \mathrm{m}^{3}$ for $\mathrm{CO}_{2}$ was higher than the WHO standards of $810 \mathrm{mg} / \mathrm{m}^{3}$ but the mean concentration value of $339.7 \mathrm{mg} / \mathrm{m}^{3}$ was found to be lower than the NIOSH permissible limits of $656 \mathrm{mg} / \mathrm{m}^{3}$ for an 8-hour exposure period. The study concluded that the percentage mean concentration of $0.05 \%$ for $\mathrm{CO}_{2}$ was slightly higher than the 
WHO standard of $0.04 \%$, but the \% mean concentration of $\mathrm{CH}_{4}$ of $0.05 \%$ was lower than the NIOSH permissible limit of $0.1 \%$ for an 8 -hour period in the Trans-Amadi industrial area.

Table 2: Meteorological Parameters and Status of GHGs around Industrial Areas in Rivers State

\begin{tabular}{|c|c|c|c|c|c|c|}
\hline Bonny & & & & & & \\
\hline Stations & $\mathrm{RH}(\%)$ & $\begin{array}{l}\text { Temp } \\
{ }^{0} \mathrm{C}\end{array}$ & $\begin{array}{ll}\text { Wind } & \text { Speed } \\
(\mathrm{m} / \mathrm{s}) & \end{array}$ & $\begin{array}{l}\text { Wind } \\
\text { Direction }\end{array}$ & $\begin{array}{l}\mathrm{CO}_{2} \\
\left(\mathrm{mg} / \mathrm{m}^{3}\right)\end{array}$ & $\begin{array}{l}\mathrm{CH}_{4} \\
\left(\mathrm{mg} / \mathrm{m}^{3}\right)\end{array}$ \\
\hline S1 & 65.4 & 31 & 1.2 & SW & 1269 & 459.9 \\
\hline $\mathrm{S} 2$ & 62.2 & 31.5 & 0.9 & $\mathrm{~S}$ & 1292.4 & 461.8 \\
\hline S3 & 66.9 & 31.6 & 1.2 & SW & 1263.6 & 462.5 \\
\hline S4 & 71.5 & 31 & 0.8 & $\mathrm{~S}$ & 1182.6 & 461.2 \\
\hline Mean & 66.5 & 31.3 & 1 & & 1251.9 & 461.4 \\
\hline *WHO & & & & & 810 & - \\
\hline **NIOSH & & & & & - & 656 \\
\hline Eleme & & & & & & \\
\hline Stations & $\mathrm{RH}(\%)$ & $\begin{array}{l}\text { Temp } \\
{ }^{0} \mathrm{C}\end{array}$ & $\begin{array}{ll}\begin{array}{l}\text { Wind } \\
(\mathrm{m} / \mathrm{s})\end{array} & \text { Speed } \\
\end{array}$ & $\begin{array}{l}\text { Wind } \\
\text { Direction }\end{array}$ & $\begin{array}{l}\mathrm{CO}_{2} \\
\left(\mathrm{mg} / \mathrm{m}^{3}\right)\end{array}$ & $\begin{array}{l}\mathrm{CH}_{4} \\
\left(\mathrm{mg} / \mathrm{m}^{3}\right)\end{array}$ \\
\hline S1 & 60.1 & 29.1 & 1 & SW & 1238.4 & 467.8 \\
\hline $\mathrm{S} 2$ & 56.4 & 28.2 & 2.6 & SW & 1117.8 & 461.8 \\
\hline S3 & 56.7 & 28.1 & 2.7 & SW & 1098 & 453.3 \\
\hline S4 & 57.7 & 28 & 1.6 & SW & 1184.4 & 440.2 \\
\hline Mean & 57.7 & 29.4 & 2 & & 1159.7 & 455.8 \\
\hline *WHO & & & & & 810 & - \\
\hline **NIOSH & & & & & - & 656 \\
\hline Omoku & & & & & & \\
\hline Stations & $\mathrm{RH}(\%)$ & $\begin{array}{l}\text { Temp } \\
{ }^{0} \mathrm{C}\end{array}$ & $\begin{array}{ll}\text { Wind } & \text { Speed } \\
(\mathrm{m} / \mathrm{s}) & \end{array}$ & $\begin{array}{l}\text { Wind } \\
\text { Direction }\end{array}$ & $\begin{array}{l}\mathrm{CO}_{2} \\
\left(\mathrm{mg} / \mathrm{m}^{3}\right)\end{array}$ & $\begin{array}{l}\mathrm{CH}_{4} \\
\left(\mathrm{mg} / \mathrm{m}^{3}\right)\end{array}$ \\
\hline S1 & 86.6 & 28.7 & 1.3 & SW & 1242 & 431.0 \\
\hline $\mathrm{S} 2$ & 82.2 & 28.8 & 1.6 & $S$ & 1227.6 & 375.9 \\
\hline S3 & 77.7 & 28.9 & 1.5 & SW & 1150.2 & 380.5 \\
\hline S4 & 78.2 & 28.8 & 1.4 & $S$ & 1213.2 & 307.0 \\
\hline Mean & 81.2 & 28.8 & 1.5 & & 1208.3 & 373.6 \\
\hline *WHO & & & & & 810 & - \\
\hline **NIOSH & & & & & - & 656 \\
\hline Rumuolume & & & & & & \\
\hline Stations & $\mathrm{RH}(\%)$ & $\begin{array}{l}\text { Temp } \\
{ }^{0} \mathrm{C}\end{array}$ & $\begin{array}{ll}\text { Wind } & \text { Speed } \\
(\mathrm{m} / \mathrm{s}) & \\
\end{array}$ & $\begin{array}{l}\text { Wind } \\
\text { Direction }\end{array}$ & $\begin{array}{l}\mathrm{CO}_{2} \\
\left(\mathrm{mg} / \mathrm{m}^{3}\right)\end{array}$ & $\begin{array}{l}\mathrm{CH}_{4} \\
\left(\mathrm{mg} / \mathrm{m}^{3}\right)\end{array}$ \\
\hline S1 & 71.4 & 30.1 & 2.7 & SW & 1112.4 & 328.0 \\
\hline S2 & 63.1 & 31 & 2 & S & 1094.5 & 331.3 \\
\hline
\end{tabular}


Vol. 4, No. 06; 2019

ISSN: $2456-8643$

\begin{tabular}{|c|c|c|c|c|c|c|}
\hline S3 & 62.1 & 31.3 & 2.6 & SW & 1108.8 & 327.4 \\
\hline S4 & 62.2 & 31.3 & 1.4 & $\mathrm{~S}$ & 1130.4 & 314.9 \\
\hline Mean & 64.7 & 30.9 & 2.2 & & 1111.5 & 325.4 \\
\hline *WHO & & & & & 810 & - \\
\hline$* *$ NIOSH & & & & & - & 656 \\
\hline \multicolumn{7}{|c|}{ Trans-Amadi } \\
\hline Stations & $\mathrm{RH}(\%)$ & $\begin{array}{l}\text { Temp } \\
{ }^{0} \mathrm{C}\end{array}$ & $\begin{array}{l}\text { Wind } \\
(\mathrm{m} / \mathrm{s})\end{array}$ & $\begin{array}{l}\text { Wind } \\
\text { Direction }\end{array}$ & $\begin{array}{l}\mathrm{CO}_{2} \\
\left(\mathrm{mg} / \mathrm{m}^{3}\right)\end{array}$ & $\begin{array}{l}\mathrm{CH}_{4} \\
\left(\mathrm{mg} / \mathrm{m}^{3}\right)\end{array}$ \\
\hline S1 & 68.8 & 30.1 & 3.9 & SW & 1051.2 & 402.2 \\
\hline $\mathrm{S} 2$ & 68.3 & 29.1 & 3.5 & $\mathrm{~S}$ & 1074.6 & 349.7 \\
\hline S3 & 70.6 & 28.1 & 2.9 & SW & 1065.6 & 265.7 \\
\hline S4 & 77.4 & 28.2 & 1.4 & SW & 1105.2 & 341.1 \\
\hline Mean & 71.3 & 28.9 & 2.9 & & 1074.2 & 339.7 \\
\hline *WHO & & & & & 810 & - \\
\hline **NIOSH & & & & & - & 656 \\
\hline
\end{tabular}

*WHO (WHO standards for $\mathrm{CO}_{2}$ ); **NIOSH (permissible limit of exposure to $\mathrm{CH}_{4}$ for 8-hour period); prevailing wind direction: SW-South-west; S-South

\section{Status of GHGs among Sampled Industrial Areas Compared}

The distribution for the status of GHGs among industrial areas revealed that Bonny industrial area in situ air measurements was highest with $1251.9\left(\mathrm{mg} / \mathrm{m}^{3}\right)$ of $\mathrm{CO}_{2}$ levels followed by Omoku industrial area with $1208.3\left(\mathrm{mg} / \mathrm{m}^{3}\right) \mathrm{CO}_{2}$ levels and Eleme industrial area with 1159.7 $\left(\mathrm{mg} / \mathrm{m}^{3}\right)$ of $\mathrm{CO}_{2}$ levels. This may be attributed to the fact that these industrial areas are heavily concentrated with companies that deals with a lot of petrochemicals different from the other two industrial areas in Rumuolumeni and Trans-Amadi. One of the by-products of petrochemicals is carbon monoxide $(\mathrm{CO})$ which have strong link with $\mathrm{CO}_{2}$ concentration in air. However, the percentage (\%) range of $\mathrm{CO}_{2}$ in air was between $0.05 \%$ and $0.07 \%$ which revealed that not much difference was observed among the industries in terms of $\mathrm{CO}_{2}\left(\mathrm{mg} / \mathrm{m}^{3}\right)$ concentrations. The level of $\mathrm{CH}_{4}\left(\mathrm{mg} / \mathrm{m}^{3}\right)$ among sampled industries also showed that the concentrations were higher under the Bonny, Eleme and Omoku industrial areas. The percentage (\%) concentrations of $\mathrm{CH}_{4}$ $\left(\mathrm{mg} / \mathrm{m}^{3}\right)$ ranged between $0.05 \%$ and $0.07 \%$. It can be deduced from the analysis that increase in the concentration of $\mathrm{CO}_{2}\left(\mathrm{mg} / \mathrm{m}^{3}\right)$ have effect on the concentration of $\mathrm{CH}_{4}\left(\mathrm{mg} / \mathrm{m}^{3}\right)$ among sampled industrial areas in the study area.

Table 3: Status of GHGs in Sampled Industrial Areas

\begin{tabular}{|l|l|l|l|l|l|l|}
\hline $\begin{array}{l}\text { Industrial } \\
\text { Areas }\end{array}$ & \multicolumn{2}{|l|}{$\mathbf{C O}_{2}\left(\mathbf{m g} / \mathbf{m}^{\mathbf{3}}\right)$} & \multicolumn{2}{l|}{$\mathbf{C H}_{\mathbf{4}}\left(\mathbf{m g} / \mathbf{m}^{\mathbf{3}}\right)$} \\
\hline & $\begin{array}{l}\text { Range } \\
(\text { Max-Min) }\end{array}$ & Mean & $\begin{array}{l}\% \\
\text { Concentration }\end{array}$ & $\begin{array}{l}\text { Range } \\
\text { (Max-Min) }\end{array}$ & Mean & $\begin{array}{l}\% \\
\text { Concentration }\end{array}$ \\
\hline Bonny & $\begin{array}{l}1292.4- \\
1182.6\end{array}$ & 1251.9 & 0.07 & $462.5-459.9$ & 461.4 & 0.07 \\
\hline Eleme & $1238.4-1098$ & 1159.7 & 0.06 & $467.8-440.2$ & 455.8 & 0.07 \\
\hline
\end{tabular}


Vol. 4, No. 06; 2019

ISSN: $2456-8643$

\begin{tabular}{|l|l|l|l|l|l|l|}
\hline Omoku & $1242-1150.2$ & 1208.3 & 0.07 & $431.0-307.0$ & 373.6 & 0.06 \\
\hline Rumuolumeni & $\begin{array}{l}1130.4- \\
1094.5\end{array}$ & 1111.5 & 0.06 & $331.3-314.9$ & 325.4 & 0.04 \\
\hline Trans-Amadi & $\begin{array}{l}1105.2- \\
1051.2\end{array}$ & 1074.2 & 0.05 & $402.2-265.7$ & 339.7 & 0.05 \\
\hline
\end{tabular}

Variation in Levels of Meteorological parameters and concentration of GHGs among Industrial areas

The results for the variations in the levels of meteorological parameters and concentration of GHGs are displayed on Table 4. It was revealed that all were significant because values of 0.000 , $0.000,0.013,0.000$ and 0.000 were lower than $\mathrm{p}$-value of 0.05 (95\% probability value). Thus, the levels of RH (\%), temperature $\left({ }^{\circ} \mathrm{C}\right)$, and wind speed $(\mathrm{m} / \mathrm{s})$ and the concentration of $\mathrm{CO}_{2}\left(\mathrm{mg} / \mathrm{m}^{3}\right)$ and $\mathrm{CH}_{4}\left(\mathrm{mg} / \mathrm{m}^{3}\right)$ significantly vary among industrial areas $(\mathrm{F}=20.812 ; \mathrm{p}<0.05),(\mathrm{F}=23.368$; $\mathrm{p}<0.05),(\mathrm{F}=4.577 ; \mathrm{p}<0.05)$ and $(\mathrm{F}=11.656 ; \mathrm{p}<0.05)(\mathrm{F}=13.773 ; \mathrm{p}<0.05)$ respectively.

Table 4: Variation in Weather parameters \& Status of GHGs

\begin{tabular}{|c|c|c|c|c|c|c|}
\hline \multicolumn{2}{|c|}{ Air quality parameters } & \begin{tabular}{|l|}
$\begin{array}{l}\text { Sum } \\
\text { Squares }\end{array}$ \\
\end{tabular} & df & Mean Square & $\mathrm{F}$ & $p<0.05$ \\
\hline \multirow[t]{3}{*}{$\mathrm{RH}(\%)$} & Between Groups & 1210.575 & 4 & 302.644 & 20.812 & $* 0.000$ \\
\hline & Within Groups & 218.123 & 15 & 14.542 & & \\
\hline & \begin{tabular}{|l|} 
Total \\
\end{tabular} & 1428.698 & 19 & & & \\
\hline \multirow{3}{*}{$\begin{array}{l}\text { Temperature } \\
\left({ }^{0} \mathrm{C}\right)\end{array}$} & Between Groups & 29.117 & 4 & 7.279 & 23.368 & $* 0.000$ \\
\hline & \begin{tabular}{|l|} 
Within Groups \\
\end{tabular} & 4.673 & 15 & .312 & & \\
\hline & Total & 33.789 & 19 & & & \\
\hline \multirow{3}{*}{$\begin{array}{l}\text { Wind speed } \\
(\mathrm{m} / \mathrm{s})\end{array}$} & Between Groups & 8.398 & 4 & 2.100 & 4.577 & $* 0.013$ \\
\hline & \begin{tabular}{|l} 
Within Groups \\
\end{tabular} & 6.880 & 15 & .459 & & \\
\hline & Total & 15.278 & 19 & & & \\
\hline \multirow[t]{3}{*}{$\mathrm{CO}_{2}\left(\mathrm{mg} / \mathrm{m}^{3}\right)$} & Between Groups & 81951.392 & 4 & 20487.848 & 11.656 & $* 0.000$ \\
\hline & Within Groups & 26364.518 & 15 & 1757.635 & & \\
\hline & Total & 108315.909 & 19 & & & \\
\hline \multirow[t]{3}{*}{$\mathrm{CH}_{4}\left(\mathrm{mg} / \mathrm{m}^{3}\right)$} & Between Groups & 493505.460 & 4 & 123376.365 & 13.773 & $* 0.000$ \\
\hline & Within Groups & 134366.850 & 15 & 8957.790 & & \\
\hline & Total & 627872.310 & 19 & & & \\
\hline
\end{tabular}

*Significant at $\mathrm{p}=0.05$

Relationship between meteorological parameters and status of GHGs in the study area The results of the Pearson correlation analysis as displayed on Table 5 revealed that the correlation between $\mathrm{RH}(\%)$ and temperature $\left({ }^{\circ} \mathrm{C}\right)$ with GHGs were weak and were not significant $(\mathrm{r}=0.154 ; \mathrm{p}<0.05) \quad(\mathrm{r}=-0.311 ; \mathrm{p}<0.05)$ and $(\mathrm{r}=0.265 ; \mathrm{p}<0.05)(\mathrm{r}=0.086 ; \mathrm{p}<0.05)$. However, a negative but strong and significant correlation was observed between wind speed 
$(\mathrm{m} / \mathrm{s})$ and concentration of $\mathrm{CO}_{2}\left(\mathrm{mg} / \mathrm{m}^{3}\right)(\mathrm{r}=-0.810 ; \mathrm{p}<0.05)$ but correlation with $\mathrm{CH}_{4}$ was weak and not significant $(\mathrm{r}=-0.364 ; \mathrm{p}<0.05)$.

Table 5: Correlation matrix between Meteorological parameters \& GHGs

\begin{tabular}{|c|c|c|c|c|c|c|}
\hline \multicolumn{2}{|c|}{ Air quality parameters } & \multirow{2}{*}{\begin{tabular}{|l}
$\mathrm{RH}(\%)$ \\
1
\end{tabular}} & \multirow[t]{2}{*}{$\begin{array}{l}\text { Temp } \\
\left({ }^{0} \mathrm{C}\right)\end{array}$} & \multirow[t]{2}{*}{\begin{tabular}{|l}
$\begin{array}{l}\text { Wind speed } \\
(\mathrm{m} / \mathrm{s})\end{array}$ \\
\end{tabular}} & \multirow[t]{2}{*}{$\begin{array}{l}\mathrm{CO}_{2} \\
\left(\mathrm{mg} / \mathrm{m}^{3}\right)\end{array}$} & \multirow[t]{2}{*}{$\begin{array}{l}\mathrm{CH}_{4} \\
\left(\mathrm{mg} / \mathrm{m}^{3}\right)\end{array}$} \\
\hline $\mathrm{RH}(\%)$ & & & & & & \\
\hline $\begin{array}{l}\text { Temperature } \\
\left({ }^{0} \mathrm{C}\right)\end{array}$ & $\mathrm{r}$ & -0.198 & 1 & & & \\
\hline $\begin{array}{l}\text { Wind speed } \\
(\mathrm{m} / \mathrm{s})\end{array}$ & $\mathrm{r}$ & -0.175 & -0.235 & 1 & & \\
\hline $\mathrm{CO}_{2}\left(\mathrm{mg} / \mathrm{m}^{3}\right)$ & $\mathrm{r}$ & 0.154 & 0.265 & $-0.810^{*}$ & 1 & \\
\hline $\mathrm{CH}_{4}\left(\mathrm{mg} / \mathrm{m}^{3}\right)$ & $\mathrm{r}$ & -0.311 & 0.086 & -0.364 & $0.562 *$ & 1 \\
\hline
\end{tabular}

${ }^{*}$ Correlation significant at $\mathrm{p}<0.05 ; \mathrm{r}-$ correlation coefficient

\section{DISCUSSION}

Descriptive statistics in the form of mean values (Table 2) and percentages in the results explanations among industrial areas were used to explain the results of the meteorological parameters and status of GHGs $\left(\mathrm{CO}_{2}\right.$ and $\left.\mathrm{CH}_{4}\right)$. Inferential statistics of ANOVA statistics and Pearson Correlation statistics were used to determine the variation in meteorological parameters and status of GHGs among industrial areas; and to determine the relationship between independent variables of meteorological parameters $(\mathrm{X})$ and dependent variables of status of GHGs (Y) in the study area.

Findings showed that he concentration of $\mathrm{CO}_{2}$ among sampled industrial areas were higher than the WHO standards of ambient air quality of $\mathrm{CO}_{2}$. This may be attributed to the release of hydrocarbons into air during industrial operations. The industrial areas are heavily concentrated with oil and gas and petrochemical industries that generate a lot of GHGs in the course of production. Findings are in agreement with Chigbo (2011) that the effects of industrialization causes increase in climate change indices such as $\mathrm{CO}_{2}$ and $\mathrm{CH}_{4}$. Findings also revealed higher values of $\mathrm{CH}_{4}$ due to industrial activities, even though, values obtained were lower than the NIOSH permissible limit of 8-hour exposure. Findings agree with the findings of Candell et al., (2019) that more $\mathrm{CH}_{4}$ is produced by human activities than all natural sources combined. Similarly, the report by Nisbet et al., (2019) that rise in concentration of $\mathrm{CH}_{4}$ is usually due to high level of industrial activities. The distribution of the status of GHGs among industrial areas revealed that Bonny industrial area recorded highest level of $\mathrm{CO}_{2}$ concentration, with Omoku industrial area ranking second in levels of $\mathrm{CO}_{2}$ concentration and the next was the Eleme industrial area. This was attributed to the fact that these industrial areas are heavily concentrated with industries and companies dealing with oil and gas refineries and petrochemical productions. The industrial area in Trans-Amadi with slightly lower $\mathrm{CO}_{2}$ and $\mathrm{CH}_{4}$ concentrations may be attributed to the less number of oil and gas and petrochemical companies and the higher level of urban greening practices observable along major road connections in the industrial area. Thus, the low level of $\mathrm{CO}_{2}$ concentrations may have been possible due to its urban greening. This finding is in agreement with Bhaskar and Shrawan (2012) that urban green infrastructures act 
sinks for atmospheric carbon dioxide $\left(\mathrm{CO}_{2}\right)$. Consequently, the higher concentration of $\mathrm{CO}_{2}$ and $\mathrm{CH}_{4}$ revealed that they are by-products of oil and gas activities and petrochemical production in the study area. The United State Environmental Protection Agency (USEPA) (2017) asserts that direct sources of the emissions of GHGs are linked to the activities of industries overtime. Findings of the study also revealed that the concentration of $\mathrm{CO}_{2}$ may have direct influence on the concentration of $\mathrm{CH}_{4}$ (Table 5) which was significant among sampled industrial areas.

\section{CONCLUSION AND RECOMMENDATION}

The study focused on analyzing the major GHGs $\left(\mathrm{CO}_{2}\right.$ and $\left.\mathrm{CH}_{4}\right)$ around some selected industrial areas in Rivers State, Nigeria. Findings revealed higher concentration of $\mathrm{CO}_{2}$ when compared with the WHO standards. The study also discovered high concentration of $\mathrm{CH}_{4}$, but slightly lower than the NIOSH permissible limit for an 8-hour period of exposure; thus, longer periods of exposure could produce deleterious effects injurious to health. The reason for the higher levels in concentration of $\mathrm{CO}_{2}$ and $\mathrm{CH}_{4}$ were linked to industrial activities in these areas. Despite the fact that, these areas were designated and developed for industrial productions with few residential properties, the trans-boundary effects of $\mathrm{CO}_{2}$ and $\mathrm{CH}_{4}$ can be felt even at residential areas in the study area. Nnaji and Chimelu (2014) have highlighted the trans-boundary effect of air pollution. For instance, wind speed significantly correlated with the concentration of $\mathrm{CO}_{2}$ in the study area. Thus, wind as a dispersal agent can function to this effect. The findings of the study revealed high concentrations of GHGs which have several health implication and environmental implications; the study therefore recommends that the government should endeavour to strengthen existing laws on air pollution. The government should do more to ensure compliance with law in order to improve ambient air quality in the study area. The use of alternative power supply is also advised in order to reduce the concentrations of GHGs in industrial areas.

\section{REFERENCES}

Canadell, P and Jackson, R (2019). Turning methane into carbon dioxide could help us Fight climate change. https;//theconversation.com/turning-methane-into-carbon-dioxide... Retrieved 2019-10-10

Eludoyin, O.S., Wokocha, C.C. and Ayolagha, G. (2011). GIS Assessment of Land Use and Land Cover Changes in OBIO/AKPOR L.G.A., Rivers State, Nigeria. Research Journal of Environmental and Earth Sciences, 3(4): 307-313

Etheridge, .M., Steele, L.P., Francey, R.J. and Langenfelds, R.L. (1998) Atmospheric methane between 1000AD and present:Evidence of anthropogenic emissions and climatic variability., Journal of Geophysical Research: Atmospheres 103(D13), 15979-15993

Igbokwe, J.I., Nnah, S.I., Ejikeme, J.O. and Igbokwe, E.C. (2016). Mapping And Analysis Of Transportation Network Of Port Harcourt, Rivers State Using Geographic Information System (GIS) And Remote Sensing. International Journal of Innovative Environmental Studies, 4(2): 1-10

IPCC (2014). AR5 synthesis report: Climate change. https://www.ipcc.ch/report/ar5/5yr/

McKenna, A. (2018). Rivers State Nigeria. https://www.britannica.com/place/Rivers... Retrieved 2019-11-10

National Academies Press (NAP) (2010). Advancing the science of climate change. Available at: https://www.nap.edu/read/12782/chapter/2 
National Bureau of Statistics (NBS) (2016). "Nigeria Poverty Profile 2016 Report”. Retrieved from: http://www.tucrivers.org/...

National Institute for Occupational Safety and Health (NIOSH) (2019). NIOSH publications by Category. Available at: https://en.wikipedia.org/wiki/National_Institute_for_Occupational_...

Nisbet, E.G., Manning, M.R., Dludokencky, E.J., Fisher, R.E., Lowry, D., et al., (2019). Very strong atmospheric methane growth in the 4 years (2014-2017): implications for the Paris agreement. Global biogeochemical cycles, 1-16

Nnaji, A.O., and Chimelu, C.C. (2014). Effects of Diesel Powered Generator Fumes on Ambient Air Quality over Lagos Island, Nigeria. Research Journal of Agriculture and Environmental Management, 3(7): 320-325

UNEP (2018). Annual report on climate change. Available at: https://www.unenvironment.org/

United States Environmental Protection Agency (USEPA) (2017). Sources of Greenhouse gas emissions. $\quad$ https://www.epa.gov/ghgemissions/sources-greenhouse-gasemissions\#transportation Retrieved 2019-11-8

WMO (2019). Weather. Climate. Water. Available at: https://www.public.wmo.int/en

Wokocha, C.C., and Omenihu, E.R. (2015). Land Resources Appraisal and Management Activities using Remote Sensing Techniques: Case Study of Akpor Town, Rivers State. Journal of Environment and Earth Science, 5(13): 145-153

World Health Organization (WHO) (2009). Air pollution guidelines. Available at: https://www.who.int/airpollution/guidelines/en/... 